Diabetologia 8, 131-135 (1972)

(c) by Springer-Verlag 1972

\title{
Biologically Active Circulating Proinsulin-Like Materials from an Islet Cell Carcinoma Patient*
}

\author{
N.R. Lazarus, R.A. Gutman, J.C. Penhos, and L. Recant \\ Veterans Administration Hospital, Diabetes Research Laboratory and Georgetown University, Department of Medicine, \\ Washington, D.C., U.S.A.
}

Received: August 30, 1971, accepted: December 21, 1971

Summary. Circulating immunoreactive insulin (IRI) material was obtained from a hypoglycemic patient with a pancreatic islet cell carcinoma. On gel filtration, $85 \%$ of this material eluted as a homogeneous proinsulin peak (PLM) and $15 \%$ as insulin. On polyacrylamide gel electrophoresis, in addition to a small amount of insulin, two peaks were obtained. One had the migration of intact human proinsulin. The second electrophoresed as an intermediate species compatible with desdipeptide proinsulin. Trypsin treatment of PLM resulted in IRI material eluting as insulin on gel filtration. When comparable amounts of IRI material were tested, PLM showed about one half of the biological activity of porcine insulin in the rat hemidiaphragm system. No evidence of conversion to insulin was found after PLM had exerted its biological activity. In addition to large amounts of proinsulin, islet cell tumors may secrete significant amounts of intermediate species into the circulation.

Substances biologiquement actives, circulantes et ressem. blant à la proinsuline chez un malade avec carcinome des cellules des îlots pancréatiques

Résumé. Une substance insulinique immunoréactive circulante (TRI) a été obtenue chez un malade hypoglycémique avec carcinome des cellules des îlots pancréatiques. Par filtration sur gel, 85\% de cette substance a été éluée comme un pic homogène de proinsuline (PLM: substance ressemblant à la proinsuline) et $15 \%$ comme l'insuline. Par électrophorèse sur gel de polyacrylamide, deux pics ont été obtenus, en plus d'une faible quantité d'insuline. L'un avait la migration de la proinsuline humaine intacte. L'autre migrait comme une substance intermédiaire compatible avec la proinsuline desdipeptidée. Le traitement de la PLM à la trypsine aboutissait à une substance IRI qui était éluée comme l'insuline par filtration sur gel. Des quantités comparables de la substance IRI ont été testées. La PLM montrait alors environ la moitié de l'activité biologique de l'insuline de pore dans le système de l'hémidiaphragme du rat. On ne trouvait aucun signe d'une conversion en insuline lorsque la PLM avait exercé son activité biologique. En plus de grandes quantités de proinsuline, les tumeurs des cellules des îlots pancréatiques peuvent sécréter des quantités importantes de substance intermédiaire dans la eirculation.

Biologisch alstive, zirkulierende, proinsulin-ähnliche Substanzen von einem Patienten mit einem Inselzellcarcinom

Zusammenfassung. Von einem hypoglykämischen Patienten mit einem Inselzellcarcinom des Pankreas wurde zirkulierendes immunoreaktives Insulin (IRI) erhalten. $\mathbf{8 5} \%$ dieses Materials wurden bei einer Gelfiltration als ein homogener Proinsulin-Gipfel und $15 \%$ als Insulin eluiert. Bei der Polyakrylamidelektrophorese wurden zusätzlich zu einer geringen Menge Insulin zwei Gipfel erhalten.Einer davon zeigte die Wanclerung von intaktem humanem Proinsulin. Der zweite wanderte als eine Zwischensubstanz, vergleichbar dem Desdipeptid-Proinsulin. Eine Trypsinbehandlung des proinsulin-ähnlichen Materials ergab eine IRI Fraktion, die wie Insulin in der Gelfiltration eluiert wurde. Bei der Untersuchung von vergleichbaren Mengen IRI zeigte das proinsulin-ähnliche Material etwa die Hälfte der biologischen Aktivität von Schweineinsulin am Z werchfell der Ratte. Es wurde keine Umwandlung in Insulin festgestellt, nachdem die proinsulinähnliche Substanz ihre Wirkung ausgeübt hatte. Zusätzlich zu großen Mengen von Proinsulin scheinen Inselzelltumoren bedeutende Mengen von intermediären Substanzen in die Zirkulation abzugeben.

Key words. Pancreatic islet cell tumor, tumor hypoglycemia, serum immunoreactive insulin (IRI), pro. insulin-like material (PLM), biological activity of proinsulin.

\section{Introduction}

This laboratory $[1,2,3]$ and others $[4,5]$ have described the presence of large amounts of proinsulinlike material (PLM) in patients with insulin secreting tumors of the islets of Langerhans. Small amounts of PLM have also been described in normal subjects $[4,6$, 7]. Both in the insulinoma patients and in normals, this PLM has been identified chiefly by its behaviour in Sephadex gel columns and by its convertibility by trypsin to a material that migrates, after gel filtration, as insulin. The possibility exists that PLM may represent not only proinsulin but also various inter-

* Supported by VA Research Funds and NIH Grant AM 11578 mediates of proinsulin $[2,8,9,10]$. The availability of serum from a severely hypoglycemic patient with a carcinoma of the islets provided us with the opportunity for a more precise identification of the circulating insulin immunoreactive material (IRI) as well as an opportunity to determine if it was biologically active.

\section{Methods}

Serum from an adult male patient with a surgically and histologically documented carcinoma of the pancreatic islets was obtained ${ }^{1}$. The patient presented with severe hypoglycemia and fasting levels of immuno-

1 Our thanks to Dr. S.J. Fajans for the serum samples. 
reactive insulin (IRI) of the order of $1100 \mu \mathrm{U} / \mathrm{ml}$. Human proinsulin and insulin standards were obtained from serum of normal obese non-diabetic subjects. To provide large amounts of circulating IRI, these subjects were stimulated with $300 \mathrm{~g}$ glucose $(150 \mathrm{~g} I V$, $150 \mathrm{~g}$ p.o.) followed by $1 \mathrm{~g}$ tolbutamide IV. Levels of IRI obtained were as high as $4000 \mu \mathrm{U} / \mathrm{ml}$ in some subjects. Additional standards included porcine proinsulin and insulin which were obtained from Eli Lilly \& Co. and which were iodinated with either ${ }^{125} \mathrm{I}$ or ${ }^{131} \mathrm{I}$ according to the method of Hunter and Greenwood [11].

Serum samples were subjected to Sephadex gel filtration. Gel filtration was performed with Sephadex G-50 superfine using columns of two sizes; large columns $2 \times 160 \mathrm{~cm}$ and small columns $1 \times 40 \mathrm{~cm}$. These columns were equilibrated either in $1 \mathrm{M}$ acetic acid or $5 \%$ albumin veronal buffer $\mathrm{pH} 8.6$. Flow rates were $1 \mathrm{drop} / 20 \mathrm{sec}(9 \mathrm{ml} / \mathrm{h})$. Three $\mathrm{ml}$ fractions were collected from the large column and $1.5 \mathrm{ml}$ fractions from the small column. Large columns permitted use of $5 \mathrm{ml}$ of serum, while $2 \mathrm{ml}$ were placed on small columns.

The $2 \times 160 \mathrm{~cm}$ Sephadex column equilibrated with $5 \%$ albumin veronal buffer $\mathrm{pH} 8.6$ was standardized by a) filtration of porcine proinsulin - ${ }^{125} \mathrm{I}$ and porcine insulin - ${ }^{131} \mathrm{I}$ dissolved in $5 \mathrm{ml}$ of serum obtained from a lean fasted subject and containing $15 \mu \mathrm{U}$ of IRI/ml, and b) serum obtained from three obese subjects stimulated with glucose and tolbutamide.

Further identification procedures were carried out on acid alcohol extracts of serum [12]. Trypsin incubation was performed as previously described [2] except that $0.5 \mathrm{mg} / \mathrm{ml}$ of trypsin were utilized. Digestion was terminated after $15 \mathrm{~min}$ by the addition of $1 \mathrm{M}$ acetic acid. Gel filtration on a $1 \times 40 \mathrm{~cm}$ column equilibrated in $1 \mathrm{M}$ acetic acid was carried out before and after trypsin treatment. After filtration, individual tubes were freeze dried and tested for IRI. Polyacrylamide gel electrophoresis was performed by the procedure of Lazarus et al. [13], utilizing a $15 \%$ polyacrylamide gel with ethylene diacrylate as the secondary polymerization agent. This method permits separation of serum IRI components and has been standardized with porcine proinsulin, porcine proinsulin intermediate species, bovine proinsulin, porcine diarginyl insulin and porcine and human insulin.

Measurements of biological activity were carried out on the rat hemidiaphragm [14] utilizing the PLM peak obtained by gel filtration (1 M acetic) of serum acid alcohol extracts. Tubes containing the PLM peak were pooled and lyophylized. Stimulation of glucose uptake by PLM with known IRI concentrations was compared with the effects of insulin standards. Activity of PLM was measured with and without anti-insulin serum to rule out nonspecific stimulation of glucose uptake. All assays for insulin immunoreactivity were carried out by the Morgan and Lazarow procedure [15] using a guinea pig anti-porcine insulin serum with human insulin standards. The assay is $1 / 3$ as sensitive to porcine proinsulin as it is to insulin in the steep portion of the curve which is essentially the only portion used. Proinsulin levels were not corrected for this difference.
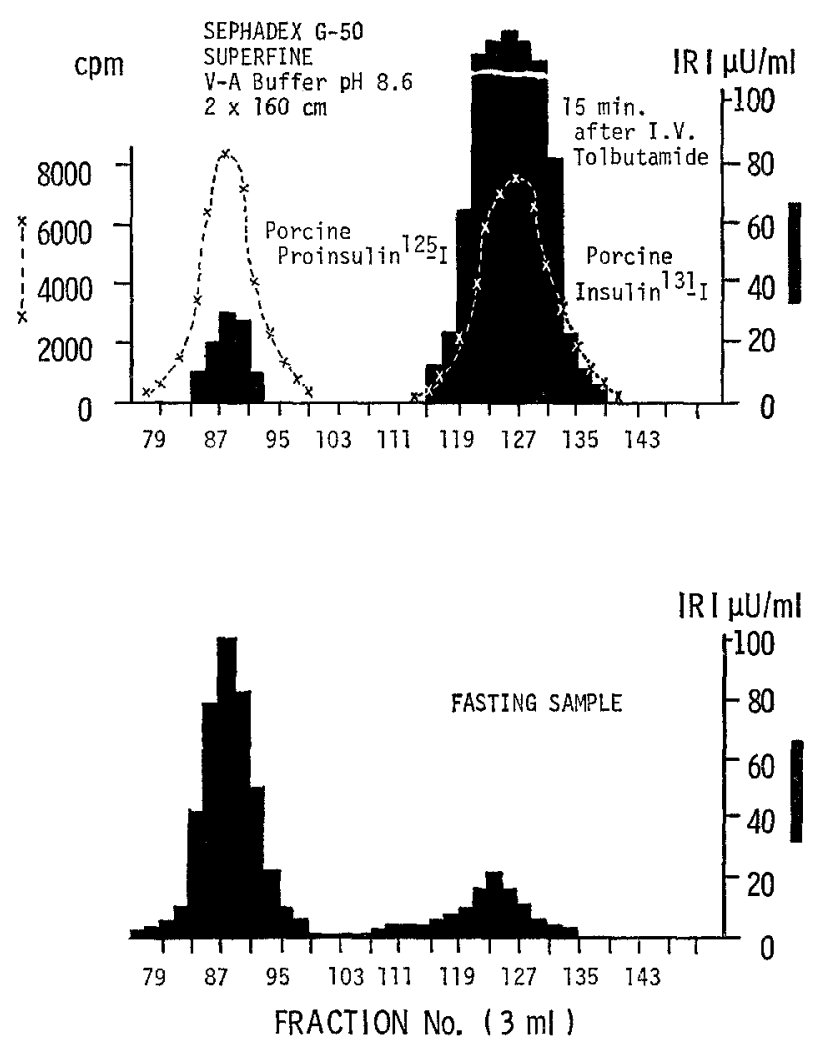

Fig. 1. Upper panel: The hatched areas show the immunoreactive elution profile of serum obtained from an obese normal subject. For conditions see methods. Elution profile of porcine proinsulin ${ }^{125} \mathrm{I}$ and porcine insulin 131I are also shown. Unlabelled proinsulin and insulin elute at similar positions to the labelled species. Lower panel: The hatched area shows the elution profile of $5 \mathrm{ml}$ of fasting serum from the patient with an islet cell carcinoma. As can be seen about $85 \%$ of the total IRI elutes as either the proinsulin standard or the PLM of an obese subject

\section{Results}

Serum from an obese subject was filtered on Sephadex G-50. The IRI elution pattern is shown in the upper panel of Fig. 1. Most of the IRI is located in the position of porcine insulin 131-I. A small but well defined peak of larger molecular size, elutes in the position of porcine proinsulin ${ }^{125}$-I. This pattern is typical of that reported for normal subjects $[3,4,6]$. The IRI elution profile of serum obtained from the patient with an islet cell carcinoma is shown in Fig. 1 (lower panel). As can be seen, $85 \%$ of the IRI elutes in the position of porcine proinsulin or human PLM. A small peak is seen in the insulin area. Serial dilution of the patient's serum reveals a linear profile of immuno- 
reactivity (Fig. 2). After an acid alcohol extract of $1 \mathrm{ml}$ of the patient's serum was electrophoresed on polyacrylamide gel (Fig. 3), three peaks are seen. The smallest has the same electrophoretic mobility as insulin, while the largest has the same mobility as proinsulin. The third peak is in an intermediate position. Fig. 4 shows the gel filtration behavior of 2 identical aliquots of acid alcohol extracts of the serum. Prior to trypsin treatment, $90 \mu \mathrm{U}$ IRI are eluted. Most of the IRI elutes in the proinsulin position (tube 19).

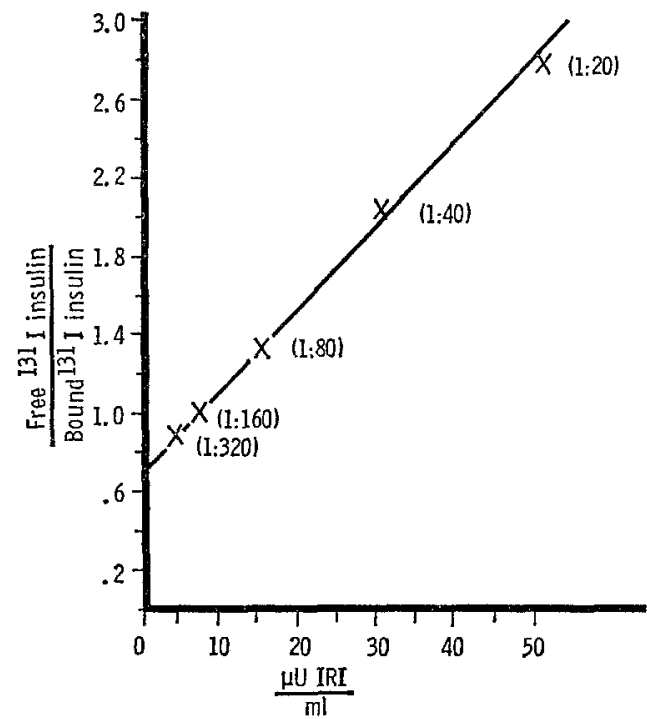

Fig. 2. The linear profile of immunoreactivity obtained on dilution of the plasma from the patient with islet cell carcinoma is shown

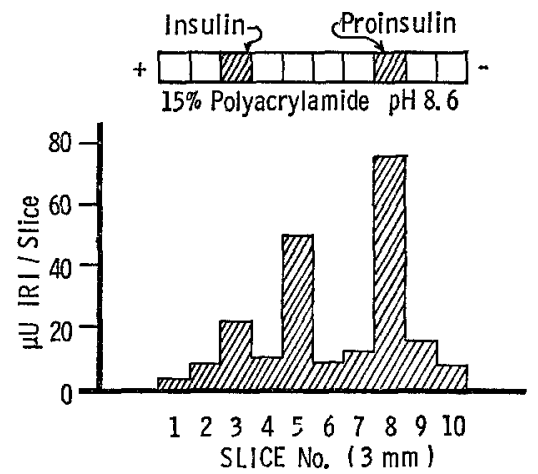

Fig. 3. The hatched area shows the immunoreactive profile obtained after electrophoresis on polyacrylamide of an acid alcohol extract of $1 \mathrm{ml}$ serum from the carcinoma patient $(900 \mu \mathrm{U} I R I / \mathrm{ml})$. Three peaks are seen. The smallest one is in the position of human insulin, the largest in the position of human proinsulin. The third peak migrates in an intermediate position

After trypsin treatment, the elution position of the IRI Peak has shifted from tube 19 to tube 25. Almost $96 \%$ of the material has been converted to an immunoreactive substance that elutes as the insulin marker.

The tryptic conversion of the PLM resulted in an approximately 2 -fold increase in immunoreactivity. A serum acid alcohol extract was filtered on G-50 Sephadex equilibrated in $1 \mathrm{M}$ acetic acid. The tubes containing the PLM peak were pooled, freeze-dried and tested for biological activity on the rat hemidiaphragm. The results are shown in Table 1. The following points are noteworthy: The proinsulin-like material produced an insulin-like effect compared with control hemidiaphragm in buffer $(+3.32 \mathrm{mg}$ glucose uptake/gm muscle in Expt. 1). $250 \mu \mathrm{U}$ of standard insulin appears as effective as $500 \mu U$ of the PLiM. Finally, the biological activity of the PLM is abolished by the addition of anti-insulin serum.

Table 1. In vitro insulin-like activity of serum proinsulinlike material from beta cell carcinoma patient

\begin{tabular}{|c|c|c|c|c|c|}
\hline \multirow[b]{3}{*}{$\begin{array}{l}\text { Expt. } \\
\text { No. }\end{array}$} & & \multirow[b]{3}{*}{$\begin{array}{l}\text { IRI } \\
\mu \mathrm{U} / \mathrm{ml}\end{array}$} & \multirow{2}{*}{\multicolumn{3}{|c|}{$\begin{array}{l}\text { Acid alc. extr. serum } \\
\text { Paired rat hemidiaphragms } \\
\mathrm{mg} / \mathrm{gm} / \mathrm{h}\end{array}$}} \\
\hline & & & & & \\
\hline & & & $\begin{array}{l}\text { Glucose } \\
\text { uptake }\end{array}$ & $\begin{array}{l}\text { Insulin- } \\
\text { like } \\
\text { effect }\end{array}$ & $\begin{array}{l}\text { No. } \\
\text { pairs }\end{array}$ \\
\hline I & Buffer & $\overline{300}$ & 3.58 & +332 & (2) \\
\hline II & $\begin{array}{l}\text { PLM } \\
\text { Insulin }\end{array}$ & $\begin{array}{l}500 \\
250\end{array}$ & $\begin{array}{l}9.20 \text { 士0.55 } \\
8.87 \pm 0.58\end{array}$ & & (4) \\
\hline \multirow[t]{2}{*}{ III } & $\underset{\text { bAIS }}{\text { PLM }}+$ & 500 & 4.39 & & \\
\hline & $\begin{array}{l}\text { Insulin } \\
+ \text { AIS }\end{array}$ & 250 & 3.64 & & (3) \\
\hline
\end{tabular}

a Material recovered after incubation and subjected to gel chromatography.

b Anti-insulin serum added in excess to the incubation medium prior to experiment. Mean value of 4 pairs of buffer incubations $4.09 \pm 0.68$ is not significantly different from the mean of anti-insulin treated samples, but is significantly different from the values obtained in Expt. II.

In order to ascertain whether the PLM had been converted to insulin during the $1 \mathrm{~h}$ incubation with diaphragm, the material incubated in Expt. 1 was recovered. The diaphragms used in Expt. 1 were removed and washed. The washings were added to the incubation medium and the total, chromatographed on a small column equilibrated in albumin-veronal buffer. The results are shown in Fig. 5. 70\% of the total immunoreactivity incubated with the diaphragm was recovered. There was no change in the elution profile after incubation.

\section{Discussion}

Our laboratory has reported that 9 of 11 patients with insulin secreting islet cell tumors show an increased level of circulating proinsulin compared with normal subjects, obese subjects and patients with functional hypoglycemia $[1,2,3]$. These findings have been supported in isolated reports $[4,5,6]$ and in a series of 20 insulinomas recently reported by Sherman 
et $a l$ [16]. In the present report, a patient with an "insulin" secreting islet cell carcinoma was shown to have $85 \%$ of his circulating insulin immunoreactivity associated with a PLM. The linear dilution pattern of IRI suggested either a homogeneous species or heterogeneity with closely related immunologic properties of the components. The PLM migrated on gel filtration as a homogeneous species in the position of either porcine proinsulin or human PLM (Fig. 1). However, the studies done on polyacrylamide gel electrophoresis demonstrated heterogeneity in that apart from proinsulin and a small insulin peak, a third peak was found

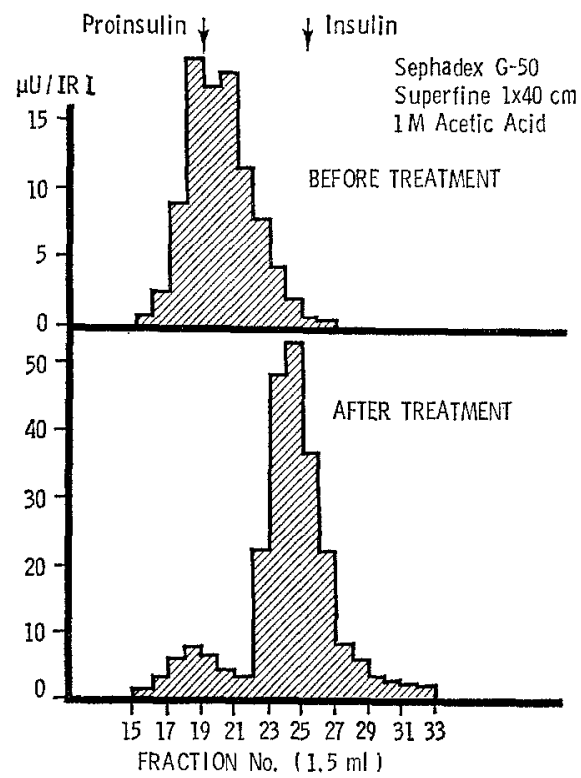

Fig. 4. Upper panel: The arrows denote the elution peaks of porcine proinsulin and insulin. The hatched area shows the immunoreactive elution profile of an acid alcohol extract of plasma from the patient with islet cell carcinoma. The immunoreactive material elutes as proinsulin. Lower panel: The immunoreactive elution pattern after trypsinization of an acid alcohol extract of the carcinoma serum is shown. Note that most of the immunoreactive material elutes as insulin. It should be noted that equilibration of the Sephadex in $1 \mathrm{M}$ acetic acid causes a decrease in its ability to discriminate between proinsulin and insulin (For comparison see Fig. 5.) The proinsulin and insulin elution positions were determined using the purified porcine species

electrophoresing in an intermediate position between proinsulin and insulin. The migration behavior of this peak was compatible with desdipeptide proinsulin, although arginyl-insulins cannot be ruled out. We have recently described circulating intermediate species with similar migration in hyperstimulated obese subjects [17]. The ability of trypsin to convert these species into material that migrates on filtration as insulin shows that the PLM is not in an unconvertible form [8].

Studies of the biological activity of $300-500 \mu \mathrm{U}$ IRI of the PLM peak revealed insulin-like activity. Further, since insulin antibody inhibited the above activity, it was concluded that this was not a "nonspecific" insulin-like effect. It appeared that the biological activity of this proinsulin-like material in the rat hemidiaphragm system was roughly $50 \%$ of that of insulin, on a $\mu$ U-equivalent basis. Thus, the severe hypoglycemic syndrome in this patient could certainly have been produced by the proinsulin-like material.

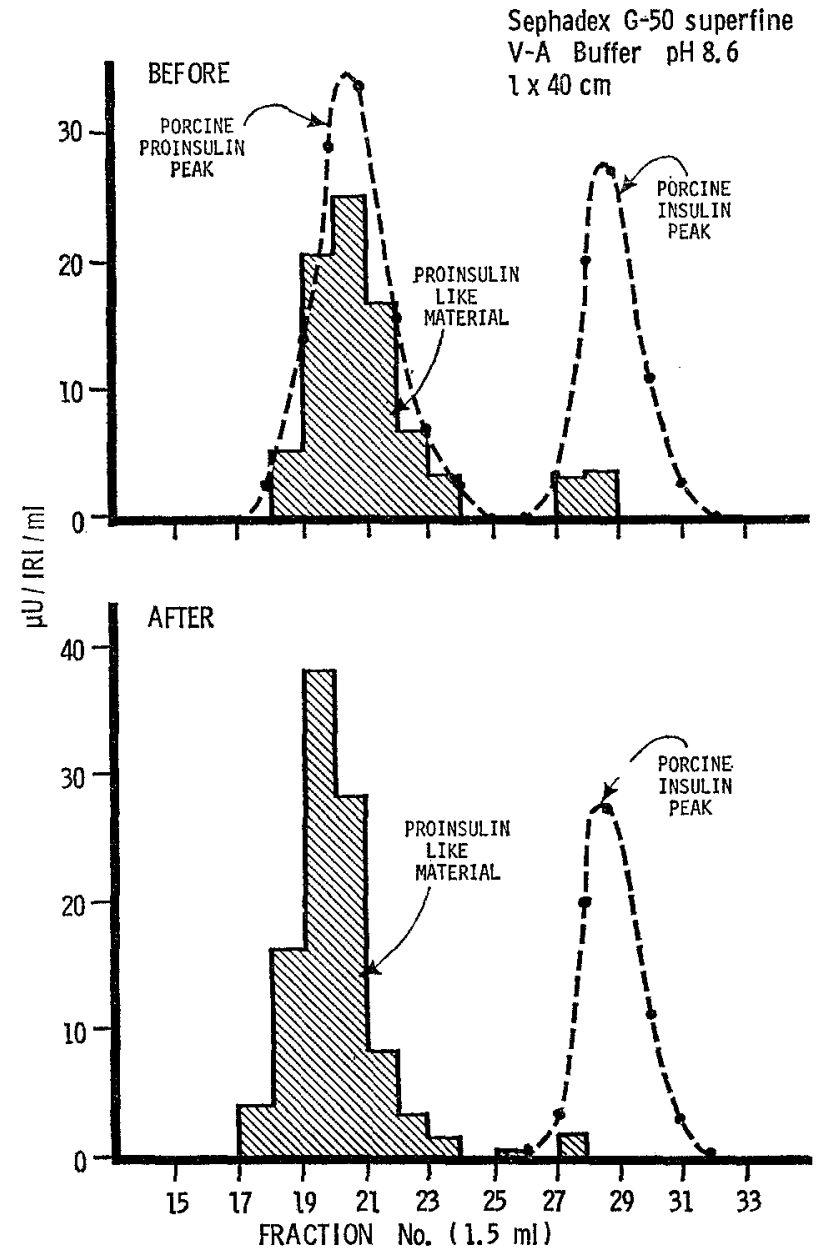

Fig. 5. Upper panel: The hatched area represents the immunoreactive elution profile of an acid alcohol extract of serum from the carcinoma patient. Only small amounts of immunoreactive material eluting as insulin are present in the serum $(10 \%)$. Lower panel: Shown is the elution profile of the immunoreactive material after incubation with the diaphragm (hatched area). There is no change in elution pattern. The elution positions of purified porcine proinsulin and insulin are shown. It should be noted that equilibration in albumin veronal buffer increases the discriminating ability of the Sephadex gel. Insulin is well separated from proinsulin

In keeping with our previous conclusions regarding the activity of proinsulin [14], it would appear that this material does not need to undergo conversion to insulin in order to elicit biological activity. This conclusion is supported by the data that rechromatographed proinsulin-like material from our patient showed the same Sephadex elution profile before and 
after incubation with rat diaphragm in vitro. Approximately $70 \%$ of the total immunoreactive material incubated with the diaphragm was recovered $(210 \mu \mathrm{U}$ out of $300 \mu \mathrm{U}$ ). The possibility remained that the $30 \%$ of the IRI material lost during incubation ( $90 \mu \mathrm{U}$ IRI) could have been converted to insulin. Since we previously demonstrated that after one hour incubation with diaphragm, at least $67 \%$ of added insulin was recoverable, in the present experiment this would have amounted to a total of $60 \mu \mathrm{U}$ (i.e., $67 \%$ of $90 \mu \mathrm{U}$ ). Even assuming that there was no increase in immunoreactivity when the material was converted from the proinsulin form to insulin, an assumption that is not warranted, $60 \mu \mathrm{U}$ could have been detected in our system. The insulin peak was well separated from the proinsulin peak, eliminating the possibility that the converted material could be masked by the large peak representing non-converted material. This finding supports the view that conversion to insulin has not taken place and that the PLM is intrinsically biologically active. However, the possibility of a conversion at the tissue receptor-site has not been ruled out.

The data presented here suggest that islet cell tumors not only secrete large amounts of proinsulin, but also an intermediate species. Although the presence of an abnormal proinsulin molecule can not be completely excluded, the following points would make that possibility unlikely: immunological and biological behavior together with convertibility by trypsin.

\section{References}

1. Lazarus, N.R., Tanese, T., Recant, L. : Proinsulin and insulin synthosis and release by human insulinoma. Diabetes 18, (Suppl. 1), 340 (1969).

2. - - Gutman, R., Recant, L. : Synthesis and release of proinsulin by human insulinoma tissue. J. clin. End. Metab. 30, 273-281 (1970).

3. Gutman, R., Lazarus, N.R., Penhos, J., Recant, L., Fajans, S. Circulating proinsulin-like material in patients with functional insulinomas. New Engl. J. Med. 284, 1003-1008 (1971).

4. Goldsmith, S., Yalow, R., Berson, A. Significance of human plasma insulin sephadex fractions. Diabetes 18, 834-839 (1969).

5. Melani, F., Ryan, W.G., Rubenstein, A.H., Steiner, D.: Proinsulin secretion by a pancreatic beta cell adenoma: proinsulin and C-peptide secretion. New Engl. J. Med. 283, 713-719 (1970).

6. Gordon, P. and Roth, J.: Circulating insulins. Arch. intern. Med. (Chicago) 123, 237-246 (1969).

7. Melani, F., Rubenstein, A.H., Steiner, D.F.: Human serum proinsulin. J. clin. Invest. 49, 497-507 (1970).

8. Steiner, D.F., Hallund, O., Rubenstein, A., Cho, S., Bayliss, C.: Isolation and properties of proinsulin intermediate forms and other minor components from crystalline bovine insulin. Diabetes 17, 725-736 (1968).

9. Chance, R.E., Ellis, R.M.: Proinsulin: Single chain precursor of insulin. Arch. intern. Med. (Chicago) 123, $229-236(1969)$

10. Tung, A.K., Yip, C.C.: Biosynthesis of insulin in bovine fetal pancreatic slices: The incorporation of tritiated leucine into a single chain proinsulin, a double chain intermediate and insulin in subcellular fractions. Proc. nat. Acad. Sci. 63, 442-449 (1969).

11. Greenwood, F.C., Hunter, W.M.: The preparation of ${ }^{181}$-labelled human growth hormone of high specific radioactivity. Biochem. J. 89, 114 (1963).

12. Davoren, P.R.: The isolation of insulin from a single cat pancreas. Biochem. biophys. Acta. 63, 150 (1962)

13. Lazarus, N.R., Gutman, R., Recant, L.: A method for the electrophoretic characterization on polyacrylamide gels of circulating insulin immunoreactive substances. Anal. Biochem. 40, 241-246 (1971).

14. - Penhos, J.C., Tanese, T., Michaels, L., Gutman, R. Recant, L.: Studies on the biological activity of porcine proinsulin. J. clin. Inv. 49, 487-496 (1970).

15. Morgan, C.R., Lazarow, L. : Immunoassay of insulin: Two antibody systems. Plasma insulin levels of normal, sub-diabetic and diabetic rats. Diabetes 12, $115-126$ (1963).

16. Sherman, B.M., Pek, S., Fajans, S.S., Floyd, J.C., Conn, J.: Plasma proinsulin in twenty patients with insulin secreting islet cell tumors. Diabetes 20, (Suppl. 1), 337 (1971).

17. Lazarus, N., Gutman, R., Recant, L. : Characterization of human circulating insulin immunoreactive sub. stances on gel filtration and polyacrylamide gel electrophoresis. Fed. Proceed. 30, 193 (1971).

Dr. Norman R. Lazarus,

Veterans Administration Hospital,

Diabetes Research Laboratory,

50 Trving St., N.W.,

Washington, D.C. 20422, U.S.A. 